\title{
Guatemala: The Fight for Accountability and the Rule of LaW
}

\author{
Guatemala: la lucha por la rendición de cuentas y el Estado de derecho
}

\section{KEVIN PALLISTER}

Bridgewater College, USA

\begin{abstract}
Guatemala's political system has been shaken by corruption scandals over the past two years. In large part, the country's political system has been consumed by efforts to fight impunity for corruption and human rights abuses. In 2015 voters elected Jimmy Morales to the presidency on an anti-corruption platform, hopeful for change from a political outsider. Throughout 2016 some advances were achieved in the fight against corruption, and prosecutors won several high-profile convictions for human rights violations that occurred during the country's civil war. But organized criminal networks continued to operate in the country, posing serious challenges to the rule of law, and both the Morales administration and the new Congress displayed some of the same shortcomings as previous governments.
\end{abstract}

Key words: corruption, impunity, rule of law, human rights

\section{RESUMEN}

Durante los últimos dos años, el sistema político guatemalteco ha sido sacudido por escándalos de corrupción. En gran parte, el sistema politico ha centrado sus esfuerzos por combatir la impunidad, la corrupción y los abusos contra los derechos humanos. En 2015 los votantes eligieron a Jimmy Morales como presidente. Con una promesa anticorrupción, Morales se presentó como un "outsider" que puede implementar un cambio. A través de 2016 se lograron algunos avances en la lucha contra la corrupción y los fiscales ganaron varias condenas de alto perfil por violaciones de derechos humanos ocurridas durante la guerra civil del país. Sin embargo, las redes de crimen organizado continuaron operando en el país, planteando graves desafíos al Estado de derecho. Ante estos retos, la administración de Morales y el nuevo Congreso mostraron deficiencias similares a las presentadas por gobiernos anteriores.

Palabras clave: corrupción, impunidad, Estado de derecho, derechos humanos 


\section{INTRODUCTION}

In recent years Guatemalan politics has centered on the pressing issues of justice, impunity, and the rule of law. In 2015, the country was consumed by corruption scandals that forced the president, vice president, and other top officials out of office. The investigations and resulting criminal proceedings continued throughout 2016, while more high-level government officials were accused of illicit behavior. At the same time, prosecutions against the perpetrators of human rights abuses during the country's civil war have proceeded, with 2016 seeing significant convictions.

These efforts to end impunity for corruption and human rights violations have been aided by the International Commission against Impunity in Guatemala (CICIG), a United Nations-supported institution formed in 2007 to investigate organized crime and assist local efforts to combat crime and corruption. By some measures, the problems of corruption and impunity have only gotten worse in the past two years. Transparency International's Corruption Perceptions Index, which uses expert surveys to measure the pervasiveness of corruption across countries, ranked Guatemala 136 (of 176 countries) in 2016, down from 123 the previous year. In 2015, Freedom House's rating of political rights in Guatemala moved from a score of 3 to 4 (on a scale of 1-7, with higher numbers indicating less freedom) "because of the increasing influence of organized crime and business interests in campaign funding, as well as the murder of municipal office candidates and their family members during the campaign" (Freedom House 2016, 19 June). The rating stayed the same for 2016.

Yet on their own these indicators can be misleading. The Attorney General's office (the Ministerio Público) continued to exert its independence throughout 2016 by investigating and prosecuting the politically powerful. It has been aided in this work by CICIG, whose mandate was scheduled to expire in 2017 before President Jimmy Morales asked the United Nations to extend the mandate until September 2019 (Human Rights Watch 2017). Efforts were also undertaken in 2016 to reform the constitution in order to strengthen the judiciary (discussed below). And while investigators and prosecutors have taken on organized crime, ordinary violent street crime has continued to decline (though it remains high by international standards) (Ellis 2016, 10 November). The homicide rate declined from 29.5 per 100,000 inhabitants in 2015 to 27.3 in 2016, continuing a downward trend seen in recent years (Gagne 2017, 16 January). ${ }^{1}$ The homicide rate in 2016 was the lowest Guatemala has seen since 2000. ${ }^{2}$

\footnotetext{
Analysts credit a regional trend of declining homicides for the drop in 2016, rather than any policy initiatives from the new Morales administration. The operating budget of the National Civilian Police (PNC) was increased five percent in 2016, but the force "remained understaffed, inadequately trained, and insufficiently funded, all of which substantially impeded its effectiveness," according to the U.S. Department of State (2017).

2 Based on data from the United Nations Office on Drugs and Crime, available at https://www.unodc.org/ gsh/en/data.html
} 
This article takes stock of the political developments in Guatemala in 2016, with a focus on corruption, human rights, and the rule of law. It begins with a brief discussion of the country's economic situation before moving on to discuss the political conjuncture facing the country as a result of the corruption scandals that emerged in 2015. It then discusses the 2015 elections before turning to the functioning of the Congress and the presidency, the efforts to amend the constitution and reform the electoral law in 2016, and the human rights situation in the country, including efforts to bring the perpetrators of crimes against humanity to justice.

\section{THE ECONOMIC CONJUNCTURE}

Guatemala's economic performance in 2016 was only modestly positive. The country's gross domestic product (GDP) grew an estimated 2.9 percent in 2016, a decrease from 4.1 percent growth the previous year. The World Bank notes that the country continues to face the persistent challenge of extremely low levels of government tax revenue and public investment (World Bank 2017). According to the National Institute of Statistics, unemployment stood at just $2.4 \%$ in late 2016, down from 3.1\% early in the year. Underemployment was substantially higher at $9.4 \%$ of the economically active population, a decline from $12 \%$ earlier in the year (INE 2017, 29 March). ${ }^{3}$

It is difficult to know if the recent corruption scandals in the country have affected foreign investment and business confidence. However, among the 279 government officials, private sector and nongovernmental representatives in Guatemala surveyed by the World Bank, public sector governance and reform was most frequently identified as a top development priority for the country. Anti-corruption was the sixth most frequently identified development priority, ahead of crime and violence (the $9^{\text {th }}$ most cited priority). This suggests that among policy elites, corruption and related issues of governance are seen as critical obstacles to Guatemala's economic performance (World Bank Group 2016).

\section{THE POLITICAL CONJUNCTURE: CORRUPTION SCANDALS AND THE PÉREZ MOLINA GOVERNMENT}

Corruption has been a longstanding issue in Guatemalan politics, and the past several presidential administrations have been tainted by corruption scandals. The most high-profile corruption case was that of former president Alfonso Portillo (2000-2004), who was accused of embezzlement and accepting bribes from Taiwan. After being found not guilty of embezzlement in a Guatemalan

Underemployment refers to individuals who work less than full time and would prefer to have full-time employment. 
court in 2011, Portillo was extradited to the United States in 2013 and served a prison sentence for money laundering until February 2015.

Officials from the government of Portillo's successor, Óscar Berger (2004-2008), have been imprisoned for money laundering, drug trafficking, and extrajudicial killings, among other crimes. During the administration of Álvaro Colom (20082012), several cabinet members were dismissed due to allegations of corruption (Lautaro Rosal 2012: 179-181). It was also widely believed that the government used the social welfare program Mi Familia Progresa for clientelist purposes to advance the political prospects of the first lady, Sandra Torres, who oversaw the administration of the program (Erbsen de Maldonado and Barahona 2010: 341-342).

Corruption scandals hit a new high in the final year of Otto Pérez Molina's presidency. The year 2015 saw a series of corruption cases and popular mobilizations that ultimately brought down the government of Pérez Molina and the Patriot Party (Partido Patriota). The case against Pérez Molina and other high ranking officials in his government came to light in April 2015 as a result of a CICIG investigation. The initial corruption scandal, known as "La Linea," involved bribes paid to customs officials to avoid paying duties on imports. The Linea network consisted of dozens of government officials, customs agents, and businessmen, and was coordinated by Juan Carlos Monzón, the private secretary of Vice President Roxana Baldetti. Baldetti and other high-ranking officials were arrested, and after large protests President Pérez Molina resigned in September 2015. Shortly thereafter he was arrested for his involvement in the Linea scheme.

Further charges and arrests connected to the Pérez Molina government continued into 2016. In April, prosecutors charged Pérez Molina, Baldetti, and others with accepting over US\$25 million in bribes from a Spanish company in exchange for a contract to build a port terminal on the Pacific coast (Pachico 2016, 18 April). The case also implicated at least two judges (Tabory 2016, 11 May). More criminal charges piled up in June, as investigators found that the Partido Patriota had set up an illegal campaign finance scheme, accepting large donations (often laundered through fictitious front companies) in exchange for government favors after winning the 2011 election (Álvarez 2016, 2 June). Pérez Molina's government delivered on its promises after the election, with investigators linking "at least 450 state contracts to the criminal structure," and finding that the campaign finance scheme "amounted to at least 500 million quetzals, or about US\$65.5 million" (LaSusa 2016, 3 June). Twenty-three people were arrested in connection with the network, and arrest warrants were issued for another forty-two.

Also in June, two former Defense Ministers and an ex-Interior Minister were arrested on corruption charges, while arrest warrants were issued for two other cabinet members (Associated Press 2016, 11 June). Investigators accused these officials of spending over $\$ 4.7$ million to buy Pérez Molina and Baldetti expensive 
gifts, including a luxury beach house and a helicopter for Pérez Molina and a vacation home in Honduras for Baldetti (Lohmuller 2016, 21 June).

So vast was the extent of corruption during Pérez Molina's presidency that prosecutors and analysts have concluded that the Partido Patriota was merely a front for a criminal enterprise to loot the state. As the Guatemalan news website Plaza Pública put it, “The Patriotic Party wasn't a political party. In reality, it was a criminal gang whose objective was to take power to rob the state" (quoted in The Economist 2016, 11 June). All told, some 200 former government officials and businessmen have been arrested in this recent wave of corruption scandals (Isaacs 2016, 14 September).

\section{THE 2015 ELECTIONS}

In response to the Linea corruption scandal, Guatemalan citizens mobilized by the thousands to demand the resignation of Pérez Molina and an end to corruption. The week following Pérez Molina's resignation, Guatemalans headed to the polls to elect a new president and Congress in September 2015. When none of the 14 candidates in the presidential race won a majority of the vote, a second round runoff vote was held in October. Given the country's mood in 2015, Guatemalan voters opted for a political outsider untainted by corruption, electing television comedian Jimmy Morales as president. As an outsider with little previous political experience, Morales ran on the attractive campaign slogan "not corrupt nor a thief." Morales won a resounding victory over Sandra Torres, a former first lady, taking 67.4 percent of the vote in the runoff. Morales took office on 14 January 2016.

The 2015 elections were mostly fair, though there were reports of vote buying and intimidation, and election-related murders occurred at the municipal level. A continuing weakness of the electoral system was the regulation of campaign finance. According to CICIG, many campaign donations came from contractors who do business with the state and from organized crime, while political parties exceeded the legal spending limits and tend to "spend more money than they report receiving" (Freedom House 2016, 19 June). On the positive side, voter turnout in the first round of voting was 71 percent, a high mark for Guatemala (OAS 2015: 3).

\section{THE EXECUTIVE AND LEGISLATIVE BRANCHES: MORE CONTINUITY THAN CHANGE}

Jimmy Morales ran under the party label of the National Convergence Front (Frente de Convergencia Nacional, FCN), a party founded in 2004 by former military officers with links to human rights violations during the country's civil war. The FCN won only 11 of the 158 seats in Congress in the 2015 election, 
suggesting that Morales could face an uncooperative Congress. The LIDER and UNE parties won the most seats in the new Congress, with 44 and 36 seats, respectively. After the new Congress was inaugurated, however, the party switching (transfuguismo) that is common among the country's legislators resulted in more than twenty members of Congress leaving their parties and joining the FCN. During the campaign, Morales had promised that he would not engage in party switching, and "denied any complicity in the logrolling, blaming his party leaders - stretching his credulity to observers" (Pérez 2016, 17 March).

Despite the presidential victory by the outsider Morales, the congressional elections were fairly typical for Guatemala. Thirteen parties won Congressional seats, resulting in a fragmented legislature. Continuing a pattern that has persisted since 2003 (Lautaro Rosal 2013: 219), no single party held a majority of seats in Congress, thus necessitating short-term coalition building to pass legislation. Several groups were underrepresented in the new Congress: only 13 percent of members of Congress elected in 2015 were women, and only 11.4 percent were indigenous (OAS 2015: 4). Both the fragmentation of the Congress and the underrepresentation of women and indigenous peoples fit the pattern that the country has experienced since the return to civilian rule in the 1980s.

Due to Morales' lack of experience, much attention focused on those he appointed to his cabinet. There were concerns that Morales would rely on members of Guatemala's traditional political class and that he would be close to military officers tied to human rights abuses (and thus impede efforts to hold people accountable for crimes against humanity committed during the war). Indeed, early in 2016 Morales was criticized for the lack of transparency in the process of selecting his cabinet and for naming members of the economic elite. Only two of the fourteen cabinet members were women, and only one was indigenous, while two cabinet ministers had served in the previous government of Pérez Molina (Soy502 2016, 14 January; Pérez 2016, 17 March).

The new cabinet got off to a rocky start when the Minister for Communications, Infrastructure, and Housing, Sherry Lucrecia Ordonez Castro, resigned due to a tax evasion scandal less than two weeks into Morales' presidency (Carasik 2016, 16 March). More problems followed later in the year. In April, the Minister of Energy and Mines, Juan Pelayo Castañón, resigned. In September, Morales fired the two top officials in the presidential security service (the Secretaría de Asuntos Administrativos y de Seguridad de la Presidencia) as the two came under investigation for "illegally spying on journalists, human rights defenders, business owners and politicians" (LaSusa 2016, 6 September). There were no indications that President Morales had ordered the illegal surveillance, though opposition lawmakers accused Morales' confidant Herbert Armando Melgar Padilla of directing the spying operation. Around this time, Melgar Padilla was named as a replacement member of Congress for the FCN, which gave him immunity from prosecution. 
Investigations into past human rights abuses and ongoing corruption also undermined the Morales administration and the FCN party. In September, the Supreme Court of Justice revoked congressional immunity from eight deputies from the FCN, allowing the Attorney General's office to begin an investigation into their alleged abuse of authority in pressuring the governor of Alta Verapaz to cede control of the department's development council (Barrios 2016, 1 September). In December, legal proceedings began against Edgar Ovalle, a congressional deputy and a top official in the FCN party accused of involvement in human rights abuses during the civil war (Ramos and Vásquez 2016, 5 December). The Supreme Court of Justice revoked Ovalle's immunity from prosecution in March 2017, and a warrant for his arrest was issued. Ovalle fled the country before being arrested, and remained a fugitive at the time of writing.

Despite his election as an anti-corruption candidate, Morales found people close to him - including family members - ensnared in a corruption scandal. Morales' oldest son, his brother Sammy Morales, and friend Gilmar Othmar Sánchez were all investigated for their role in the "Botin Registro de la Propiedad" case. The case involves the misuse of funds and illicit contracts at the Property Registry, including contracts involving the restaurant Fulanos \& Menganos, to which Jimmy and Sammy Morales have ties (Pellecer and Estrada 2016, 20 September; Prensa Libre 2017, 19 January). Morales' son and brother were arrested in January 2017 in connection with the case (Menchu 2017, 18 January). There were also reports in 2016 that a drug trafficker had given US\$500,000 to Jafeth Cabrera, Morales' vice president - though the accusation had not been proven (Bargent 2016, 23 September).

The year also saw other corruption cases against high-profile political and business figures. One investigation found that two former congressmen and a former president of the central bank, along with businessman Francisco Morales Guerra (known as "Chico Dólar," or Dollar Boy), "conspired to launder money used to illegally finance the 2011 presidential campaign of the National Unity of Hope [UNE] party" (Clavel 2016, 20 September). In January, a former mayor of Antigua was arrested on corruption charges as the result of an investigation supported by CICIG, indicating that CICIG and the attorney general's office were heavily focused on corruption at the municipal level (Gagne 2016, 22 January). Another mayor, Carlos Darinel Aguirre of La Libertad, was assassinated in October. He was suspected of involvement in drug trafficking and of having links to the Huista criminal network in Huehuetenango (Yagoub 2016, 27 October). Also in October, former congressional deputy and President of Congress Gudy Rivera was convicted and sentenced to 13 years in prison for attempting to bribe a judge in 2014 to secure a ruling favorable to then-vice president Baldetti (CERIGUA 2016, 28 October).

Controversy and scandal also affected the judiciary. Two magistrates on the Supreme Court of Justice, Vladimir Aguilar and Douglas Charchal, stepped down after being implicated in corruption scandals during the Pérez Molina 
presidency. Investigations into corruption and influence peddling by judges continued into 2017.

Amid continuing corruption scandals, by the end of 2016 President Morales had seen his approval rating plummet. After enjoying an optimistic $82 \%$ approval at the beginning of his term, Morales held a 61\% approval rating in May, placing him third highest among Latin American presidents. But Morales' approval rating had dropped to just $19 \%$ by the end of his first year in office. ${ }^{4}$ According to a national survey in September-October 2016 by Borge y Asociados, only $8 \%$ of Guatemalans believed the country was better compared to how it had been during the Pérez Molina administration, while 61\% said it was the same and $30 \%$ said it was worse. Only $23 \%$ thought the country would be better off by the end of Morales' term in office. However, most Guatemalans continued to hold a positive view of Morales personally: $59.5 \%$ of respondents had a favorable view of Morales, compared to $35.3 \%$ with an unfavorable view. Corruption was the most frequently identified principal problem facing the country $(22.3 \%)$, followed by unemployment (20.8\%) and security (15.1\%) (Borge y Asociados 2016).

Numerous Guatemalan social scientists and analysts have characterized Morales as an inexperienced and ineffective leader. Critics commonly note the lack of transparency in Morales' appointment of government ministers, department governors, and magistrates to the Constitutional Court, as well as ineffective communication from the executive branch to the Guatemalan public (CERIGUA 2016, 11 February; Contreras Corsantes 2016, 22 April; Espina Cespina 2017, 9 January). Perhaps the most common criticism of Morales was that he lacked a strategic vision or governing plans (Contreras Corsantes 2016, 22 April). This is not surprising, as Morales did not offer much of a policy platform during the campaign. As the BBC reported, "his campaign manifesto was only six pages long, [and] little is known about Mr Morales' policies, apart from favouring low taxes and limited government" (BBC News 2015, 26 October). Others noted that Morales' agenda during the campaign was "essentially devoid of issues" (Raderstorf and Florsheim 2015, 22 October).

There were some positive accomplishments during Morales' first year. Tax collection increased after Morales named Juan Francisco Solórzano Foppa to head the tax administration agency (Superintendencia de Administración Tributaria, SAT). The SAT was credited with cracking down on tax evasion (López 2016, 19 December). However, the administration failed to get a tax reform bill passed in Congress. Another success was increasing access to free medicines for Guatemalans (Telesur 2017, 14 January). On balance, however, Morales' first year in office was lackluster, with few significant achievements.

Approval ratings from the beginning and end of Morales' first year in office are from polls conducted by the University of San Carlos. The May 2016 approval rating is from a CID-Gallup poll. See Suncar (2016, 26 May) and Telesur (2017, 7 March). 


\section{ATTEMPTS AT INSTITUTIONAL CHANGE: CONSTITUTIONAL AND ELECTORAL REFORMS}

Largely in response to the corruption scandals that delegitimized the country's political institutions, Guatemala began to debate constitutional and legal reforms aimed at improving the functioning of the judicial system and reducing the influence of criminal networks in electoral politics. The process of reforming the justice system began in April, when the National Dialogue Toward Justice Reform in Guatemala was established. Through the Dialogue, regional meetings were held across the country over several months to debate proposed reforms and get input from different social sectors (Beltrán 2016). Many segments of civil society participated, with the dialogues supported by a technical secretariat headed by CICIG, the attorney general's office, and the human rights ombudsman's office. The result was a draft constitutional reform bill consisting of 25 amendments, which was submitted to Congress in October.

The proposed amendments would create a National Council of Justice that would oversee judicial careers and promotions and replace the selection commissions that nominate magistrates to the courts. Currently, Supreme Court magistrates are nominated by postulation committees composed of law school deans, a university rector, the Bar Association, and appellate court judges (Beltrán 2016, 12 September). Critics argue that these postulation committees have been unduly influenced by outside interests, including criminal groups. If the proposed reform is approved, the new National Council of Justice would nominate the magistrates. The new council would be composed of judges from different levels of the court system, along with professionals appointed by judges and the legislative and executive branches. Decisions about promotions and other administrative features of the judicial branch would also be transferred from the Supreme Court of Justice to the National Council of Justice, in response to concerns that the Supreme Court magistrates use their administrative powers to influence lower court rulings (del Águila 2017, 11 May).

The proposed constitutional amendments would also weaken the existing political immunity rules that prevent a wide range of public officials from being investigated or detained before a judge waives their immunity (through a preliminary antejuicio hearing). These preliminary hearings are often lengthy, thus delaying the prosecution of corrupt officials. This proposal was supported by Attorney General Aldana (Lohmuller 2016, 10 June). The constitutional reforms would also recognize indigenous judicial processes, allowing these communities "to exercise judicial functions in accordance with their own rules, procedures, uses, and customs provided that they are not contrary to rights protected by the Constitution and international human rights law" (Beltrán 2016, 12 September).

Ultimately the proposed amendments ran into opposition in Congress, with the first two amendments receiving votes from fewer than half of legislators (passage requires two-thirds majority followed by ratification by a popular 
referendum). Consideration of further amendments was then delayed until 2017 (Beltrán 2016, 12 September).

Nevertheless, Congress did pass a law in June that reformed the judicial system. Among other things, the law created a Council of Judicial Careers (Consejo de la Carrera Judicial) which would oversee disciplinary actions taken against judges. The law was supported by the attorney general's office and CICIG. Within days of the law taking effect, however, the judges' association challenged the law's constitutionality (Gramajo 2016, 29 June; Palma 2016, 27 November).

Efforts to reform the Electoral and Political Parties Law met with more success. Reforms had initially been approved by Congress and the Constitutional Court in 2013, but were never approved in final form. In April 2016, electoral reforms were finally passed by Congress, responding to widespread demand from civil society groups. The reforms increased penalties for violations of campaign rules (including campaign finance regulations), increased access to the media for smaller parties, and extended the right to vote for president to Guatemalans living abroad, while also increasing the size of Congress from 158 to 160 deputies. The reform package also included a provision that an election's result would be annulled if null votes accounted for more than half the votes cast. As with the electoral reforms of previous years, however, demands for quotas for women and indigenous Guatemalans were not included in the final bill. Such quotas would require parties to include a specified percentage of female and indigenous candidates in their party lists (NDI 2016, 20 May).

Perhaps most notably, the electoral reform (along with reforms to the Organic Law of Congress passed in February) restricted transfuguismo, or partyswitching by members of Congress. This practice, which has been widespread in Guatemala for many years, results in large numbers of congressional deputies leaving the party under whose label they were elected and joining a different party. In just the first three months of the new Congress in 2016, 44 percent of congressional deputies switched parties. The new rules would prohibit deputies who renounce their party affiliation from joining a different party, and would remove them from any congressional committees or leadership positions (Gramajo 2016, 13 April).

After approving the electoral reform bill, President Morales promised to take up further reforms to the electoral law that were not included in the bill passed in April. Civil society organizations then put together a proposal and sent it to Morales, who submitted it to Congress as a bill. The proposal included gender and ethnic quotas, permitting the formation of district-level political parties, lengthening the terms of magistrates on the Supreme Electoral Tribunal (TSE), and introducing automatic voter registration (Hernández and Contreras 2016, 8 August). This package of reforms had not been passed by Congress as of early 2017. 


\section{THE RULE OF LAW: COMBATTING IMPUNITY FOR HUMAN RIGHTS VIOLATIONS}

Guatemala has faced substantial challenges in establishing the rule of law for many years. In addition to problems of street crime and governmental corruption, the country has struggled to come to terms with the legacies of its civil war. After the center-left candidate Álvaro Colom won the 2007 presidential election, some positive steps were taken to enforce the rule of law and address crimes of the civil war era. Colom took steps to declassify military documents and increased reparations payments to those whose loved ones were killed during the war (Booth et al. 2015: 192). He also named the fiercely independent Claudia Paz y Paz as Attorney General in 2010. However, Colom presided over a period of increasing violence and insecurity in the country. Mexican drug cartels operated in the country's northern departments, leading Colom to declare a state of siege in Alta Verapaz and Petén. Homicides and widespread criminal attacks on bus companies and their employees (which were the targets of extortion rackets) contributed to a general sense of insecurity in the country.

In 2011, the right wing Otto Pérez Molina was elected president. Pérez Molina is a former military officer and was widely suspected of having been involved in human rights atrocities during the civil war. During his tenure as president, concerns grew about the use of military forces to violently repress protesters. In one incident in Totonicapán in 2012, seven people were killed when soldiers opened fire on protesters (Lautaro Rosal 2013: 211). On a positive note, Guatemala signed the Rome Statute to join the International Criminal Court during Pérez Molina's presidency (Lautaro Rosal 2013: 210).

In recent years Guatemala has taken steps to provide justice for human rights abuses committed during the civil war, and that trend continued in 2016. The most well-known case is the 2013 conviction of military ruler Efraín Ríos Montt on charges of genocide and crimes against humanity. However, that verdict was quickly overturned by the Constitutional Court on procedural grounds. A closed-door retrial did not begin until March 2016, after Montt had been found mentally unfit for a conventional trial (Human Rights Watch 2016: 1). The retrial is still ongoing.

In recent years, other members of the military and police have been convicted for human rights abuses committed during the civil war. Two former police chiefs have received lengthy prison sentences (Human Rights Watch 2016: 2). One prominent conviction resulted from the Sepur Zarco case, in which two former military officers were convicted in 2016 for crimes against humanity. The case involved the forced disappearance of fifteen male villagers and the abduction, enslavement, and systematic rape of eleven Q'eqchi' women during the war. The officers were sentenced to over 100 years in prison. The case marked "the first time that a national court has ever heard charges of sexual and domestic enslavement committed during a civil war" (Eulich 2016, 26 February). 
In January 2016, 18 former military officers were arrested for their alleged role in massacres and disappearances during the war. Among those arrested were Manuel Benedicto Lucas García, who served as the army chief of staff during the rule of his brother, General Romeo Lucas García, as well as a former military intelligence chief and a general who helped carry out the country's 1982 military coup (Malkin 2016, 6 January). The charges are based on more than 500 bodies that have been exhumed at a military base in Cobán the Comando Regional de Entrenamiento de Operaciones de Mantenimiento de Paz, or CREOMPAZ). These recent prosecutions have been aided by forensic work, in particular by the Guatemalan Forensic Anthropology Foundation, "which, in excavations of secret cemeteries and mass graves since the early 1990s, has compiled a voluminous record of military attacks on civilians during the war" (Elbein 2016, 5 April).

Investigations into human rights crimes committed during the war have also affected the Morales administration. As mentioned above, FCN congressman and secretary general Edgar Justino Ovalle is being investigated for his role in human rights abuses, specifically the CREOMPAZ case. And while most prosecutions for crimes committed during the war have aimed at former military officials, at least one conviction has been handed down for a former guerrilla. In July 2014, Felipe Solano Barillas was convicted for ordering a massacre of civilians in El Aguacate in 1988. He received a 90-year prison sentence (Human Rights Watch 2016: 2).

There was progress in 2016 in prosecuting other high profile crimes, as well. In April, five men were convicted and sentenced to lengthy terms for the 2011 murder of Argentine folk singer Facundo Cabral in Guatemala City. The five men convicted (four Guatemalans and one Costa Rican) were sentenced to 50 years in prison. In October, thirteen soldiers were arrested for the death of a civilian youth, whom they allegedly beat to death in 2015 .

While Guatemala has seen a number of high profile prosecutions against perpetrators of human rights abuses, the human rights situation in the country remains troubling. Domestic and international human rights organizations have documented harassment, intimidation, and violence targeted at human rights and environmental activists, labor organizers, and journalists. This is a continuation of a pattern of abuses against Guatemalan activists, particularly those involved in labor organizing and those working on indigenous peoples' land rights in opposition to mining and hydroelectric projects. Other human rights violations during 2016 included the involvement of police in kidnappings and extortion, harsh prison conditions, human trafficking, arbitrary arrest, and prolonged pretrial detention (United States Department of State 2017).

By December 2016, nine Guatemalan journalists had been killed during the year, according to the Guatemalan organization CERIGUA. This was an increase from three journalists killed in 2015. In one case in June 2016, journalist Álvaro Alfredo Aceituno López was killed by two gunmen in the town of Coatepeque. 
Aceituno was often critical of local government officials, but as is the case for many journalists killed, it is unclear if the murder was politically motivated (Freedom House 2016, 19 June; Otis 2016, 19 December). In previous years some killings of journalists have clearly been in response to reporting that exposed corruption. For instance, in March 2015 reporter Danilo López was killed after receiving "threats for his reporting on local government corruption;" two police officers were arrested for the murder (Amnesty International 2017). In response to pressure from media outlets and an association of journalists, the Attorney General's office "created a special unit to investigate crimes against journalists," although critics note that it "is understaffed and underfunded" (Otis 2016, 19 December).

Human rights, environmental, and labor activists continued to face harassment, intimidation, and violence in 2016. The Unidad de Protección a Defensores y Defensoras de Derechos Humanos de Guatemala (UDEFEGUA, 21 December) reported 14 murders and seven attempted murders against civil society activists through November, and a total of 223 acts of aggression (including threats, harassment, and arbitrary detention) against activists (UDEFEGUA 2016, 21 December). For instance, environmental activist Walter Mendez Barrios was murdered in March, trade unionist Brenda Marleni Estrada Tambito was murdered in June, and an employee with the Centro de Acción Legal, Ambiental y Social de Guatemala (CALAS) was murdered in November. The violence against human rights activists drew a statement of concern from the European Union (CERIGUA 2016, 18 August).

Activists faced other forms of harassment and intimidation as well. Amnesty International reported a pattern of "[1]engthy, unfounded criminal investigations against defenders [of human rights] coupled with the use of preventive detention as a general rule rather than an exception in cases involving defenders" (Amnesty International 2016, 29 August: 55). The offices of the nongovernmental organization Impunity Watch were ransacked in June (Amnesty International 2016, 24 June), and the home of a prominent human rights lawyer, Ramón Cadena Rámila, was ransacked by men posing as police officers in August. In September, masked men attacked a leader of the Comité de Unidad Campesina (CERIGUA 2016, 5 September). Threats extended to highlevel officials as well, as Attorney General Thelma Aldana faced death threats (Lakhani 2016, 15 August).

One high-profile case showed that criminals could also be targeted seemingly with impunity. In July, one of Guatemala's most famous prison inmates, former army captain Byron Lima Oliva, was murdered. Lima had been convicted for killing Bishop Juan José Gerardi, who had overseen the 1998 publication of the church's report on war crimes. Once in prison, Lima "built a powerful criminal operation from behind bars" (Malkin and Wirtz 2016, 18 July), running the prison like a kingpin and being allowed to leave prison at will. Some people suspect that Lima was killed because he might be a witness against Pérez Molina, Baldetti, and others - in particular for his suspected role in arranging 
an assassination attempt against Attorney General Aldana (Dudley 2016, 25 July). Rumors circulating about the motives behind Lima's murder suggest the widespread reach of criminal organizations tied to the former president.

Despite significant violations of human rights in the country, there were victories for human rights activists in 2016. The Supreme Court of Justice indefinitely suspended the mining activities at La Puya, a gold mine that had been the scene of protests by local communities. The Court found that local communities had not been consulted before the mining license had been granted in 2011 (Pitán 2016, 19 June). (Nevertheless, mining operations at the site continued illegally in the months after the court ruling.) Congress also passed a law aimed at improving investigations into missing women, a step intended to help combat human trafficking (Latin Correspondent 2016, 29 January). The Ministry of National Defense also "elevated its Office of Human Rights to a directorate, providing it direct access to the minister; more than doubled its personnel; and conducted active outreach to human rights organizations" (United States Department of State 2017).

One point of continuing concern for some human rights activists was the militarization of security policy. In 2015, nine special public security squadrons consisting of military personnel were created to support the national police force. Some of these squadrons have been deployed in indigenous territories where conflicts over land and resource extraction have taken place, potentially in violation of the 1996 peace agreements that called for demilitarizing these areas (Amnesty International 2016, 29 August:18). In 2016, President Morales continued the use of the military for public security functions that had been started by his predecessor.

\section{CONCLUSION: PROGRESS MADE AND THE ROAD AHEAD FOR GUATEMALAN DEMOCRACY}

Guatemala has seen many positive signs for its democracy over the past two years. In response to corruption scandals, many thousands of Guatemalans protested peacefully for months in 2015. Ultimately, the case of Otto Pérez Molina and the Partido Patriota was resolved within the constitutional rules a fact worth noting in a country that has had its share of military coups and self-coups (auto-golpes). Ultimately the president, vice president, and other top officials stepped down and faced justice, while elections were held as scheduled and power was transferred peacefully to the new government. It is a positive sign that such an enormous corruption scandal did not turn into a constitutional crisis.

The corruption scandals that emerged in 2015 and continued through 2016 also highlight the independence of the Attorney General's office. A sitting president was forced to resign and was then quickly arrested; dozens of high-level officials have been charged; and the new President's son and brother have been 
arrested for illicit activities. The fact that Guatemalan prosecutors, with the help of CICIG, have gone after such powerful political actors is a positive sign for the rule of law in the country. This is all the more impressive considering that Attorney General Thelma Aldana was appointed by Pérez Molina, and many believed that she would not exercise the independence that her predecessor, Claudia Paz y Paz, had exercised during her tenure.

Recent scandals have also demonstrated the independence and efficacy of CICIG, which has brought advanced investigative techniques such as wiretapping and forensic accounting to Guatemala. CICIG's mandate was scheduled to expire in 2017, but President Morales has already requested an extension until 2019. It is not clear if Guatemala would be able to continue attacking corruption and organized crime effectively without the help of CICIG. The Attorney General's office has acted independently, and Guatemala has established the Intendencia de Verificación Especial (IVE), a well-regarded banking oversight unit that coordinates its efforts with the Attorney General's office to go after the finances of organized crime (Ellis 2016, 10 November). But it remains to be seen how well these agents of accountability will be able to operate without the international support that CICIG embodies. And with impunity for crimes as high as 97 percent, according to CICIG Commissioner Iván Velásquez (Contreras 2016, 14 March), Guatemala's criminal justice system also still has a long way to go in fighting ordinary street crime.

The fight against impunity has also made progress in the arena of human rights. The prosecutions and convictions of military officers responsible for committing atrocities during the country's 36-year civil war provide justice for some of the survivors, and perhaps offer a degree of national healing of the wounds that the war inflicted. Some cases remain ongoing, but the hard-won convictions of the past few years would have been unthinkable at the time the peace accords were signed in 1996.

Despite these advances, many challenges remain, and the consolidation of the gains made in recent years is far from certain. Some challenges will involve maintaining the momentum in the fight against government corruption. While many officials at the national level have been indicted on corruption charges, many of the politicians who have replaced them are believed to be little better. Less progress has been made in holding local government officials accountable, although CICIG and the Attorney General's office have indicated a growing focus on corruption at the local level. As the Pérez Molina corruption cases show, the pervasiveness of corruption in Guatemala will require sustained campaigns of investigation and prosecution, along with a mobilized citizenry that demands honesty in their public officials. It is possible, however, that the "islands of honesty" represented by local investigators and CICIG can change the calculus that politicians face, leading to an equilibrium in which illicit activities are considered too risky to undertake (Taub 2016, 9 December). 
Consolidating the progress made so far against corruption and impunity may become more difficult in the years ahead. CICIG already faces a backlash from the far right, led by the Foundation against Terrorism, which has filed a legal complaint against the CICIG commissioner for the organization's investigations into crimes committed during the war. Commissioner Velásquez has also been the target of a smear campaign, while Guatemalan judges and the Attorney General have received death threats. The criminal networks that have been targeted by CICIG and Guatemalan prosecutors can be expected to continue to fight back against efforts to eliminate corruption and impunity. As Anita Isaacs (2016, 14 September) argues, the success of CICIG and its local allies "was built on the element of surprise. No one expected such a forceful assault on corruption. But organized crime won't make the same mistake twice." Organized criminal groups and corrupt politicians will likely adapt to improved investigative techniques (such as wiretaps) by changing their tactics to avoid detection. At the same time, they will continue to threaten those who stand up against impunity. The fight for the rule of law will require perseverance and ingenuity in the years ahead.

Other challenges will involve the functioning of the electoral system and political parties. Stronger regulations on campaign financing will help provide greater transparency of the origins of campaign funds. Electoral reforms passed in 2016 are a step in this direction, but it will be up to the Supreme Electoral Tribunal to implement the reforms effectively. Guatemala also faces the difficult task of building stronger political parties that represent marginalized groups and provide coherent policy platforms from which voters can choose. Recent reforms to reduce transfuguismo in Congress are a step in the direction of creating more institutionalized parties and combating the corruption that occurs when parties offer inducements to legislators to switch parties. But the country has a long history of a highly volatile party system, with parties based more on personalities and patronage than on policy platforms. Changing this pattern will take sustained efforts at institution building by politicians and social movement organizations.

Although the Morales administration and the new Congress have so far displayed many of the same weaknesses and shortcomings of previous governments, the rule of law and the functioning of democracy in Guatemala made some important advances in 2016. The difficult work ahead for civil society organizations, activists, and honest government officials will be to consolidate those gains and continue the fight for accountability and the rule of law. 


\section{REFERENCES}

Álvarez, Carlos. 2016, 2 June. "Estructura del PP recibió al menos q500 millones en sobornos." Prensa Libre. Retrieved from. http://www.prensalibre.com/guatemala/justicia/justicia---mp-y-cicig-revelan-detalles-de-operativos.

Amnesty International. 2016, 29 August. "'We Are Defending the Land with Our Blood': Defenders of the Land, Territory and Environment in Honduras and Guatemala." Retrieved from http://www.amnestyusa.org/research/reports/we-are-defending-theland-with-our-blood-defenders-of-the-land-territory-and-environment-in-honduras

Amnesty International. 2016, 24 June. “Guatemala: Anti-Impunity Organization's Offices Raided." Retrieved from https://www.amnesty.org/en/documents/document/?indexNumber $=$ amr $34 \% 2 f 4318 \% 2 f 2016 \& l a n g u a g e=e n$

Amnesty International. 2017. “Guatemala 2016/2017." Retrieved from https://www.amnesty.org/en/countries/americas/guatemala/report-guatemala/

Associated Press. 2016, 11 June. "Guatemala Arrests 3 Ex-Cabinet Ministers, Hunts for 2 More." Retrieved from http://bigstory.ap.org/article/aca1de3e8c9e4cbf925c0d97cb99c290/guatemala-arrests-2-ex-cabinet-ministers-hunts-3-more

Bargent, James. 2016, 23 September. "Revelations Add to Guatemala President's Corruption Woes." Insight Crime. Retrieved from http://www.insightcrime.org/news-briefs/revelations-add-to-guatemala-president-corruption-woes

Barrios, Fervin. 2016, 1 September. "Retiran inmunidad a 8 diputados de FCN denunciados por racismo y abuso de autoridad." Noticias de Guatemala. Retrieved from http:/ / noticias.com.gt/nacionales / 20160901-retiran-inmunidad-8-diputados-fcn-denunciados-racismo-abuso-autoridad.html

BBC News. 2015, 26 October. "Guatemala Election: Jimmy Morales Elected President." Retrieved from. http://www.bbc.com/news/world-latin-america-34632485

Beltrán, Adriana. 2016, 12 December. “Guatemala at a Crossroads: Reinforce the Fight against Corruption or Reinstate the Hidden Powers?" Washington Office on Latin America (WOLA). Retrieved from https://www.wola.org/analysis/guatemala-crossroads-reinforce-fight-corruption-reinstate-hidden-powers /

Booth, John A., Christine J. Wade, and Thomas W. Walker. 2015. Understanding Central America: Global Forces, Rebellion, and Change. Boulder: Westview Press

Borge y Asociados. 2016. "Encuesta nactional de opinión pública, septiembre 2016." Retrieved from http://borgeyasociados.com/wp-content/uploads/2016/11/Borge-Encuesta-Nacional-de-OMNIBUS-Guatemala-Setiembre-2016.pdf

Carasik, Lauren. 2016. 16 March. “Jimmy Morales Can't Fix Guatemala." Foreign Policy. Retrieved from http:/ / foreignpolicy.com/2016/03/16/guatemala-morales-perez-molina/

CERIGUA. 2016, 11 February "Grupo Multisectorial pide al Presidente reconsidere secretismo en designación de magistrados." Retrieved from https:/ /cerigua.org/article/grupo-multisectorial-pide-al-presidente-reconsider /

CERIGUA. 2016, 18 August. “Diez Activistas de DDHH han sido asesinados en Guatemala Denuncia UE." Retrieved from https://cerigua.org/article/diez-activistas-de-ddhh-han-sido-asesinados-en-gua/

CERIGUA. 2016, 5 September. "Dirigente del CUC sufrió un atentado en Alta Verapaz." Retrieved from https://cerigua.org/article/dirigente-del-cuc-sufrio-un-atentado-en-alta-verap/

CERIGUA. 2016, 28 October. "Gudy Rivera sentenciado a 13 años de prisión inconmutables." Retrieved from https://cerigua.org/article/gudy-rivera-sentenciado-a-13-anos-deprision-incon/

Clavel, Tristan. 2016, 20 September. "Central Banker Bargains Way Out of Prison in Guatemala." Insight Crime. Retrieved from http://www.insightcrime.org/news-briefs/ central-banker-bargains-way-out-of-prison-in-guatemala 
Contreras Corsantes, Geovanni. 2016, 22 April. "Cien días de gobierno: evaluación al Presidente Jimmy Morales." Prensa Libre. Retrieved from http://www.prensalibre.com/ guatemala/politica/cien-dias-de-gobierno-evaluacion-al-presidente-jimmy-morales

Contreras, Virginia. 2016, 14 March. "Velásquez: nivel de impunidad en el país supera el 97 por ciento." La Hora. Retrieved from. http://lahora.gt/velasquez-nivel-de-impunidad-en-el-pais-supera-el-97-por-ciento/

del Águila, José. 2017, 11 May. “Que no lo engañen: así funcionará el Consejo Nacional de Justicia." La Hora. Retrieved from http://lahora.gt/no-lo-enganen-asi-funcionara-consejo-nacional-justicia/

Dudley, Steven. 2016, 25 July. “The Murder of Guatemala's Prison 'King' Byron Lima: A 'Self Coup d'etat'?" Insight Crime. Retrieved from http://www.insightcrime.org/news analysis/ the-murder-of-guatemala-s-prison-king-byron-lima-a-self-coup-d-etat-part-iii

Elbein, Saul. 2016, 5 April. "The Field of Battle Is the Courts of Justice.'” Foreign Policy. Retrieved from http://foreignpolicy.com/2016/04/05/guatemala-civil-war-rios-montt-united-nations/

Ellis, Evan. 2016, 10 November. “The Struggle Against Organized Crime in Guatemala." Latin America Goes Global. Retrieved from http://latinamericagoesglobal.org/2016/11/ struggle-organized-crime-guatemala/

Erbsen de Maldonado, Karin and Marco Antonio Barahona M. 2010. “Guatemala: danzando con las crisis económica y política." Revista de Ciencia Política 30 (2): 335-360.

Espina Cespina, Cindy. 2017, 9 January. "Lo bueno y lo malo de un año de gobierno de Jimmy Morales." El Periodico. Retrieved from. https://elperiodico.com.gt/nacion/2017/01/09/lo-bueno-y-lo-malo-de-un-ano-de-gobierno-de-jimmy-morales /

Eulich, Whitney. 2016, 26 February. "Guatemala War Crimes Verdict Breaks Grip of Impunity." Christian Science Monitor,. Retrieved from http://www.csmonitor.com/World/ Americas/2016/0226/Guatemala-war-crimes-verdict-breaks-grip-of-impunity

Freedom House. 2016, 19 June. "Fifth Journalist Murdered in Guatemala This Year." Retrieved from https:/ / freedomhouse.org/article/fifth-journalist-murdered-guatemala-year

Freedom House. 2017. "Freedom in the World 2016: Guatemala." https: / freedomhouse.org/ report/freedom-world/2016/guatemala

Gagne, David. 2016, 22 January. “Ex-Mayor's Arrest Kicks off Guatemala Anti-Corruption Campaign." Insight Crime. Retrieved from http:/ /www.insightcrime.org/news-briefs / ex-mayor-arrest-kicks-off-guatemala-anti-corruption-campaign

Gagne, David. 2017, January 16. “InSight Crime's 2016 Homicide Round-Up.” Insight Crime. Retrieved from http://www.insightcrime.org/news-analysis/insight-crime-2016-homicide-round-up

Gramajo, Jessica. 2016, 13 April. “El 44\% de los diputados son tránsfugas." Prensa Libre. Retrieved from http://www.prensalibre.com/guatemala/politica/el-44-de-los-diputados-son-transfugas

Gramajo, Jessica. 2016, 29 June. "Aprueban nuevas normas para jueces y magistrados." Prensa Libre. Retrieved from http://www.prensalibre.com/guatemala/justicia/nueva-ley-fortalece-la-carrera-judicial

Hernández, M., and G. Contreras. 2016, 8 August. “Retoman reformas a la ley electoral y de partidos políticos." Prensa Libre. Retrieved from http:/ / www.prensalibre.com/sociedad-civil-entrega-reformas-a-la-ley-electoral-y-de-partidos-politico

Human Rights Watch. 2016. "Guatemala Country Summary." Retrieved from https:/ / www. hrw.org/world-report/2016/country-chapters/guatemala

Human Rights Watch. 2017." Guatemala Country Summary.". Retrieved from https:/ /www. hrw.org/world-report/2017/country-chapters/guatemala

INE [Instituto Nacional de Estadística]. 2017, 29 March. “Encuesta nacional de empleo e ingresos 3-2016." Retrieved from https://www.ine.gob.gt/sistema/uploads/2017/03/29/ 8FciGNFOtT2FJnkTOS0pTzPcDOW8FpLB.pdf 
Isaacs, Anita. 2016, 14 September. "Guatemala's Fragile Progress." New York Times. Retrieved from https://www.nytimes.com/2016/09/15/opinion/guatemalas-fragile-progress. $\mathrm{html}$ ?ref=opinion\&_r=1

Lakhani, Nina. 2016, 15 August. "Human Rights Lawyer's Home Ransacked in Guatemala in Latest String of Attacks." The Guardian. Retrieved from https://www.theguardian. com/world/2016/aug/15/guatemala-human-rights-laywer-attack-ramon-cadena-ramila

LaSusa, Mike. 2016a, 3 June. "Ex-President of Guatemala Facing More Corruption Charges." Insight Crime. Retrieved from http://www.insightcrime.org/news-briefs/guatemala-authorities-allege-ex-president-led-illegal-campaign-finance-network

LaSusa, Mike. 2016b, 6 September. "Guatemala President Fires Security Service Chiefs Accused of Spying." Insight Crime. Retrieved from http://www.insightcrime.org/ news-briefs / guatemala-president-fires-security-service-chiefs-accused-of-spying

Latin Correspondent. 2016, 29 January. "Guatemala Passes Law to Prevent Trafficking of Women." Retrieved from http://latincorrespondent.com/2016/01/guatemala-passes-law-to-prevent-trafficking-of-women/

Lautaro Rosal, Renzo. 2012. "Escenarios de fragilidad política, balance político. Guatemala 2010-2011." Revista de Ciencia Política 32 (1): 171-191.

Lautaro Rosal, Renzo. 2013. "Guatemala: recambio político y conflictividad endémica." Revista de Ciencia Política 33(1): 207-224.

Lohmuller, Michael. 2016, 10 June. "Guatemala AG Seeks End of Law Facilitating Official Impunity." Insight Crime. Retrieved from. http://www.insightcrime.org/news-briefs / guatemala-ag-seeks-end-of-law-facilitating-official-impunity

Lohmuller, Michael. 2016b, 21 June. "Guatemala's Government Corruption Scandals Explained." Insight Crime. Retrieved from http://www.insightcrime.org/news-analysis/ guatemala-s-government-corruption-scandals-explained

López, Kimberly. 2016, 19 December. “El primer año de Jimmy Morales: ¿Esperanza o desilusión?" La Hora. Retrieved from http:/ /lahora.gt/primer-ano-jimmy-morales-esperanza-desilusion/

Malkin, Elisabeth. 2016, 6 January. "Guatemala Arrests Former Military Officers in Connection With Massacres." The New York Times. Retrieved from https://www.nytimes.com/2016/01/07/world/americas/guatemala-arrests-former-military-officers-in-connection-with-massacres.html

Malkin, Elisabeth and Nic Wirtz. 2016, 18 July. "Byron Lima Oliva, Bishop's Killer, Dies in Attack at Guatemala Prison." The New York Times. Retrieved from https://www. nytimes.com/2016/07/19/world/americas/guatemala-byron-lima-oliva-killed.html

Menchu, Sofia. 2017, 18 January. "Guatemala President's Brother, Son Held on Suspicion of Fraud." Reuters. Retrieved from http://www.reuters.com/article/us-guatemala-corruption-idUSKBN1522NS

NDI [National Democratic Institute]. 2016, 20 May. "Historic Reform Is A Big Step Forward for Guatemalan Democracy." Retrieved from https://www.ndi.org/Guatemala_LEPP_ Reform_story

OAS [Organization of American States]. 2015. "Report to the Permanent Council: Electoral Observation Mission - Guatemala: Presidential, Legislative, Municipal, and Central American Parliamentary Elections." http://www.oas.org/es/sap/deco/moe_informe/Informe_MOE_Guatemala2015_e.pdf

Otis, John. 2016, 19 December. "Searching for Answers in Murder Cases amid Violence and Corruption in Guatemala." Committee to Protect Journalists. Retrieved from https:/ / cpj.org/blog/2016/12/searching-for-answers-in-murder-cases-amid-violenc.php

Pachico, Elyssa. 2016, 18 April. "Guatemala Ex-President Received Millions in Bribes from Spanish Company." Insight Crime. Retrieved from http://www.insightcrime.org/ news-briefs/guatemala-ex-president-received-millions-in-bribes-from-spanish-company 
Palma, Claudia. 2016, 27 November. “Jueces y magistrados impugnan Ley de La Carrera Judicial." Prensa Libre. Retrieved from http://www.prensalibre.com/guatemala/ justicia/jueces-y-magistrados-presentan-inconstitucionalidades-a-la-ley-de-la-carrera-judicial

Pellecer, Martín Rodríguez and Javier Estrada. 2016. 20 September. "Corruption Casts a Shadow Over Another Guatemala President." Insight Crime. Retrieved from http:// www.insightcrime.org/news-analysis/corruption-casts-shadow-another-guatemala-president

Pérez, Orlando J. 2016, 17 March. “Guatemala and Its Comedian President." Latin America Goes Global. Retrieved from http:/ / latinamericagoesglobal.org/2016/03/2767/

Pitán, Edwin. 2016, 19 June. “CSJ suspende en definitiva mina en La Puya." Prensa Libre. Retrieved from http://www.prensalibre.com/guatemala/justicia/csj-suspende-en-definitiva-mina-en-la-puya

Prensa Libre. 2017, 19 January. "MP presenta antejuicio contra Gilmar Sánchez Herrera." Prensa Libre. Retrieved from http://www.prensalibre.com/guatemala/justicia/mp-presenta-antejuicio-contra-gilmar-sanchez-herrera

Raderstorf, Ben and Haley Florsheim. 2015, 22 October. "Guatemala's Elections: 'Not Corrupt, Not a Thief.'” The Dialogue. Retrieved from http://www.thedialogue.org/ blogs/2015/10/guatemala-election-brief-not-corrupt-not-a-thief/

Ramos, Jerson and Byron Rolando Vásquez. 2016, 5 December. “Diputado Édgar Ovalle es arraigado por caso Creompaz." Prensa Libre. Retrieved from http://www.prensalibre.com/guatemala/justicia/edgar-ovalle-diputado-de-fcn-es-arraigado

Soy502. 2016, 14 January. “¿Quiénes son los ministros de Jimmy Morales?” Soy502.Com. Retrieved from http:/ / www.soy502.com/articulo/quienes-son-ministros-jimmy-morales

Suncar, Joel. 2016, 26 May. "Popularidad de Morales lo ubica tercero en Latinoamérica." Prensa Libre. Retrieved from http://www.prensalibre.com/guatemala/politica/popularidad-de-morales-lo-ubica-tercero-en-latinoamerica

Tabory, Sam. 2016, 11 May. "Guatemala Judge Stripped of Immunity in Port Corruption Case." Insight Crime. Retrieved from http:/ / www.insightcrime.org/news-briefs/guatemala-judge-stripped-of-immunity-in-port-corruption-case

Taub, Amanda. 2016. 9 December. "How 'Islands of Honesty' Can Crush a System of Corruption." The New York Times. Retrieved from https:/ /www.nytimes.com/2016/12/09/ world/asia/south-korea-brazil-argentina-impeachment.html

Telesur. 2017, 14 January. "Guatemalan President Jimmy Morales Marks 'Inefficient' 1st Year." Retrieved from http:/ / www.telesurtv.net/english/news/Guatemalan-President-Jimmy-Morales-Marks-Inefficient-1st-Year-20170112-0017.html

Telesur. 2017, 7 March. “¿Por Qué Los Guatemaltecos Exigen La Renuncia de Jimmy Morales?" Retrieved from http://www.telesurtv.net/news/Por-que-los-guatemaltecos-exigen-la-renuncia-de-Jimmy-Morales-20170307-0023.html

The Economist. 2016, 11 June. “Corruption in Guatemala: Bad Apples Everywhere." Retrieved from http:/ / www.economist.com/news/americas/21700418-ousted-president-accused-masterminding-kleptocracy-bad-apples-everywhere

UDEFEGUA. 2016, 21 December. "Guatemala: alerta ante la intensificación de las agresiones a defensores y defensoras de derechos humanos." Retrieved from http://udefegua. org/wp-content/uploads/2015/08/Guatemala_2016.12.21_CP_Conjunto_ES.pdf

United States Department of State. 2017. “Guatemala 2016 Human Rights Report." Retrieved from https://www.state.gov/j/drl/rls/hrrpt/humanrightsreport/index.htm\#wrapper

World Bank. 2017. "Guatemala Overview." Retrieved from http:/ / www.worldbank.org/en/ country/guatemala/overview

World Bank Group. 2016. "FY 2016 Guatemala Country Opinion Survey Report." Retrieved from http:/ / microdata.worldbank.org/index.php/catalog/2820 
Yagoub, Mimi. 2016, 27 October. “Murdered Guatemala Mayor Allegedly Linked to Drug Traffickers." Insight Crime. Retrieved from http://www.insightcrime.org/news-briefs/ murdered-guatemala-mayor-allegedly-linked-to-local-dto

Kevin Pallister is an Assistant Professor of Political Science at Bridgewater College in Virginia, USA. He received his Ph.D. in political science from the University of Massachusetts Amherst. His research focuses on election administration and democracy in Latin America, and he is the author of the book Election Administration and the Politics of Voter Access (Routledge, 2017). Email: kpallister@ bridgewater.edu 
- 